\title{
Türkiye'de 2000'li Yıllarda Konut Arsası Sunusu: Yeni Kurumsal İktisat Çerçevesinde Bir Değerlendirme
}

\author{
Housing Land Supply in Turkey in 2000's: \\ An Evaluation From the Perspective of New Institutional Economics
}

\author{
(1) Güneş UYANIKER, (1) Elif ALKAY
}

ÖZ

Konut arsası sunusu, planlama disiplinin geniş bağlamda tartıştı̆̆ı ve ekonomi politikalarıyla doğrudan ilişki kuran en önemli konularından biridir. Bir yandan nüfus ve yerel dinamiklerin etkisiyle tetiklenen kentsel gelişme ve ekonomi politikaları sununun büyüklüğü ve formunu belirlerken, öte yandan bu gelişmeden en yüksek faydayı sağlamayı bekleyen arazi sahipleri ve inşaat şirketleri göz ardı edilemez bir baskı unsuru olmaktadırlar. Tüm bunların yönlendirilmesinde devlet en etkin rolü üstlenmekte ve müdahalelerini kurumlar ve yasalar aracılığıyla yürütmektedir. Türkiye örneğinde, 2002 sonrası kendisinin de konut arsası sunusunda temel aktörlerden biri haline geldiği devlet neoliberal ekonomi politikalarının hakimiyetinde konut arsası sunusunu nasıl yönlendirmektedir? Bu araştırma sorusu çalışmanın kavramsal çerçevesini ve araştırma yöntemini belirlemiştir. Mevcut durumun yapısal analizi Yeni Kurumsal iktisat (YKi) teorisi bağlamında kavramsallaştııımış ve yapılmıştır. YKi, neoklasik iktisadın kurumları inmal ettiği gözleminden yola çıkarak önemli olanın devlet tarafından yaratılan kurumların doğası ve kurumların tanımladığı kurallar olduğu noktasına vurgu yapar. Hatta kurumlar bir toplumun gelişmesine yol açarken bazı durumlarda geri kalmışlığın temel nedeni olarak ortaya çıkabilmektedir. Bu sebeple çalışmada konut talebinin karşılanmasına yönelik olarak devletin planlama aracılığıyla yarattığı konut arsası sunusunda kurumsal yapı ve yasal düzenlemelerin incelenmesinde kurumlar ve kuralları odak alan yaklaşımından yararlanılmıştır. 2000'ler sonrasındaki planlama mevzuatı ve kurumsal yeniden yapılandırmaya yönelik düzenlemeler geniş bir doküman analizine tabi tutulduğunda, devletin konut arsası sunusunda kendini yeniden ölçeklendirdiği ve en güçlü aktörlerden biri olarak belirdiğini söylemek mümkündür. YKí teorisiyle uyumlu olarak, doküman analizi, konut arsası sunusunda, kurumsal ve yasal düzenlemelerin iyi kurgulanmadığı durumda enformalite, karşılıkııık ilişkileri ve belirsizliklerin arttığını göstermektedir. Ayrıca, tam bilgilendirmenin sağlandığı bir konut arsası piyasası yaratılamadığından bireyler sınırlı rasyonalite ile davranışlarını belirleyeceklerdir.

Anahtar sözcükler: Arsa sunusu; devlet; konut sektörü; kurum; planlama; yeni kurumsal iktisat.

\section{ABSTRACT}

Housing land supply is one of the most important issues that the planning discipline discusses from the several perspectives. On the one hand, population, local dynamics and economic policies that stimulate urban development have substantial impact on the size and form of the housing land supply, on the other hand, landowners and construction companies, who are aimed to get the highest benefits from housing construction, are powerful on directing both central and local governments land policies. This study aims to investigate this new housing land supply regime by focusing on institutional restructuring period and legal arrangements. In order to understand the structural reforms, and consequently, the role of central and local governments in housing land supply, new institutional economics (NIE) is applied as methodological approach.NIE focuses on institutions and formal rules in order to understand structural characteristics of the market and behaviour of market actors. In our case, the planning system to the extent of institutional structure and planning regime along with legal arrangements is structurally analysed in order to understand the current housing land supply regime. A comprehensive documentary analysis, including both institutional restructuring and legal arrangements, has been done to reflecting the structural changes in 2000s.Documentary analysis obviously reflects the dominant role of the state in new housing land supply regime. However, because of the inherent characteristics of the planning system and conflicts in power use of central and local governments, the conditions of perfect information and certainty in the land supply market is enable to create. Mutual relations is the other factor that disturb the housing land supply regime. Therefore, uncertainties in market conditions is high and actors behave in bounded rationality. Consequently, the new housing land supply regime is seen not be enable to create concreate market conditions to actors and not supported by consistent housing policies.

Keywords: Land supply; state; housing; institution; planning; new institutional economics.

İstanbul Teknik Üniversitesi Mimarlık Fakültesi, Şehir ve Bölge Planlama Anabilim Dalı, İstanbul 


\section{Giriş}

Inşaata dayalı ekonomik büyüme, 2000'li yılların ikinci yarısından itibaren farklı boyutları ile tartışma gündemi oluşturmaktadır. En önemli tartışma konularından biri gayrimenkul odaklı büyüme ve ani sermaye birikiminin sürdürülebilir olup olmadığıdır. Nitekim The Economist tarafindan geliştirilen ve ülkelerin ani sermaye çıkışlarından etkilenme derecesini ölçen Sermaye Donma Endeksi sıralamasına göre Türkiye ikinci kırılgan ülkedir. ${ }^{1}$ Bir diğer tartışma konusu da benimsenen ekonomik büyüme modelinin mekan üstündeki etkileridir. Bu doğrultuda tartışma büyüme sürecinde etkili mekânsal planlama kararlarının kapsam ve içeriği yanı sıra bu kararların uygulama süreçleri üstünde yoğunlaşmaktadır. Ayrıca, sermaye birikim süreçleri ilerletilirken, kamu menfaatinin gözetilmesinde devlet politikaları ve müdahaleleri de tartışmanın önemli bir parçası haline gelmektedir. Süreçte kamu açısından oluşacak belirsizliklerin ortadan kaldırılması devletin temel görev alanı olarak görülmektedir. Mekânsal planlama bu bağlamda kullanılan en etkin araçlardan biridir. Kaynakların nasıl kullanılacağı ve dolayısıyla nasıl dağıtılacağına karar veren planlama eylemi, mülk sahiplerinin bu kaynak kullanımından elde edecekleri fayda düzeyini belirlediği için önem kazanmaktadır. ${ }^{2}$ Dinamik nüfus yapısı ve ekonomik konjonktüre bağlı olarak hızlı kentsel gelişmeye sahne olan kentsel alanda sermaye sahipleri ve kent yöneticilerinin arasındaki en yaygın tartş̧ma konusunu konut arsa sunusu oluşturmaktadır. Planlar yoluyla hem toplam sunu büyüklüğü hem de bu büyüklük içinde yapılabilecek toplam inşaat alanı belirlenir. Unutulmamalıdır ki devlet, kurumsal ve yasal düzenlemeleriyle bu sununun niceliksel ve niteliksel olarak temel belirleyicisidir. Dolayısıyla devlet, konut piyasasında düzenleyici, yön gösterici, ayrıca, belirsizlik ortamından doğabilecek çelişkileri çözen ve süreci yönetendir.

Friedmann (2005) mevcut bütün planlama sistemlerinin iç ve dış kaynaklı değişimlere uyum sağlamak için sürekli olarak yenilendiğinden bahsetmektedir. ${ }^{3}$ Benzer biçimde Türkiye örneğinde de devlet, benimsenen büyüme politikasının uzantısında 2000'li yılların ilk yarısından itibaren planlama kurumsal yapısı ve mevzuatında köklü değişiklikler yapmıştır. Altınok'a (2012) göre 1980-2000 yılları döneminden farklı olarak 2000'li yıllar sonrasının önemi, neoliberal politikaların kurumsallaştrılmasıdır. ${ }^{4}$ Dolayısıyla bu kurumsallaşmanın yapısal analizi, içinde bulunduğumuz durumu anlayabilmek için zorunlu hale gelmiştir.

Bu çalışmanın amacı, neoliberal ekonomi politikalarının yönlendirmesiyle kentsel ölçekte gerçekleşen konut arsa sunusunun Yeni Kurumsal iktisat (YKi) yaklaşımı doğrultusunda kavramsallaştrılması ve sunu sürecinin yapısal ana-

\footnotetext{
(http://www.economist.com/ 2 Campbell\&Marshall, 2000, s. 297. blogs/graphicdetail/2015/09/capi- 3 Friedmann, 2005.

tal-freeze-index). $\quad 4$ Altinok, 2012, s. 85.
}

lizinin ortaya konmasıdır. YKi'ın en temel ayırt edici özellikleri belirsizliklerin giderilmesinde kurumsal yapıya büyük önem atfetmesi ve disiplinler arası çalışmasıdır. Ayrıca YKi neoklasik ekonomik teoriye, piyasanın iç güçleri doğrultusunda kendiliğinden denge durumunu bulacağı, ve piyasa koşulları hakkında tam bilgilendirmenin sağlandığı varsayımları nedeniyle, ilaveten, yalnızca değer teorisini bir faktör olarak ele alışı nedeniyle eleştirel bakar. Bu nedenle, YKi bu çalışmada, yapısal analiz sürecinde kavramsallaştırma ve analitik inceleme için metodolojik yaklaşımın temellerini oluşturmuştur. ${ }^{5}$ Belirtilen çalışma amacı doğrultusunda araştırma soruları: a) devlet, planlama yoluyla konut arsa sunusunu, dolayısıyla konut piyasasını nasıl yönlendirmektedir? b) devlet bu süreçte hangi aktörler/kurumlar ile işbirliği yapmakta ve kendini nasıl ölçeklendirmektedir?

İzleyen bölüm YKi teorisinin temel özelliklerinin özetlendiği ve neoklasik ekonomik teoriden farklılaştiğı noktaların ortaya konduğu bölümdür. Ardından YKi ve planlama arakesiti kavramsallaştırması yapılmıştır. Bu kavramsallaştırma, özellikle 2000 'li yıllar sonrasında yapılan kurumsal ve yasal düzenlemeler bağlamında konut arsası sunusu konusuna odaklanılarak somutlaştrılmıştr. Son bölüm ise YKi perspektifinden bir genel değerlendirme ve tartışma bölümüdür.

\section{Planlama ve Konut Arsası Sunusu: Yeni Kurumsal İktisat Çerçevesinden Bakış}

Yerleşik iktisadi görüşün bireyi temel alan yaklaşımına eleştiri getiren ve iktisat biliminin temel inceleme alanı olarak kurumların alınması gerekliliğini vurgulayan kurumsal iktisat genel olarak ana akım kurumsal iktisat ve YKi diye ikiye ayrılabilir. Öncülüğünü Williamson'ın (1975) yaptığı YKi, oyun kuralları ve mübadeleler üzerine tartş̧an Axelrod (1984), mülkiyet hakları üzerine tartşan Alchian ve Demsetz (1973), belirsizlik üzerine tartı̧̧an Knight (2003), aktörler üzerine tartşan Olson (2000), kurum, organizasyon üzerine tartışan North (1991), işlem maliyetlerini analizlere katan Coase (1937) ile birlikte konvansiyonel metotlardan ayrılan, çok kapsamlı ve yeni bir metodoloji sunmuştur. ${ }^{6}$ YKi, hakim iktisadi bilgeliği reddetmeden ancak neoklasik iktisadi analizlerin temellendiği varsayımları sert bir biçimde eleştirip olay temelli (event-base) analizleri öne çıkararak yerleşik iktisadi gündemin merkezinde yerini almıştr. ${ }^{7}$ YKi'ın söylem farklıııkları şu şekilde özetlenebilir:

- YKi düşünürleri iktisadi olayları bütünlükçü bir paradigma ile açıklamak yerine, bireylerin davranış ve yönelimleri ile açıklamayı tercih ederler, ${ }^{8}$

- YKI düşünürleri tam rasyonalite varsayımını eleştirir ve bireylerin sınırlı rasyonaliteye (bounded rationa-

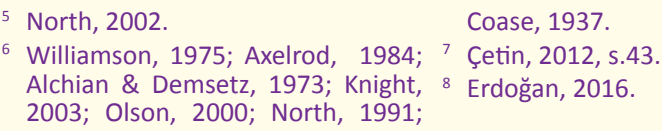


lity) sahip olduğunu, iktisadi kararlarını fayda maksimizasyonu için değil, tatmin duygusuyla yönlendirdiklerini öne sürerler. Sınırlı rasyonaliteden kasıt ise bireylerin gözlemlenemez olaylar ve belirsizlik karşısında sınırlı zihinsel kapasiteye sahip olduğu, bu nedenle olayların gelişimi hakkında tam bilgiye sahip olamayacaklarıdır, ${ }^{9}$

- YKi, iktisat yanı sıra hukuk, politika, sosyoloji ve organizasyon teorisi ile temas halindedir ve bu nedenle disiplinler arasıdır, ${ }^{10}$

- YKi, neoklasik iktisadın 'Görünmez El' söylemi yerine 'Dengeleyici Güç' kavramını kullanır; iktisadi yaşamda denge durumundan sapma söz konusu olduğunda dengeleyici güç devreye girecektir ki bu noktada siyasal otorite tartş̧manın merkezinde yer alır, ${ }^{11}$

- Kurum anlayışı, ekonomik teori ve ampirik bilgiyi geniş bir yelpazede ekonomik, kültürel ve politik ortamlara uygulamaya izin verecek kadar zengin olmalıdır, ${ }^{12}$

- YKi, Neoklasik iktisadın iktisadi işlemlerin belirlilik varsayımı altında bedelsiz olarak gerçekleştiği varsayımını eleştirir ve "işlem maliyeti" kavramını öne sürer. Sınırlı rasyonalite işlem maliyetlerinin doğmasına yol açmaktadır, ${ }^{13}$

- YKi, geleceğe ilişkin belirsizlik, sınırlı rasyonalite, pozitif işlem maliyetleri, mülkiyet haklarının tam olarak tanımlanamaması ve firsatçılık gibi problemler nedeniyle sözleşmelerin tam olmayacağını iddia etmektedir, ${ }^{14}$

- YKi yaklaşımında iktidar ve iktidarı oluşturan dinamiklerin incelenmesi esas önemdedir. ${ }^{15}$

Özetle YKi, piyasa sürecinde işlem maliyetlerinin asgari düzeye çekilebilmesi için aktörlerin önündeki belirsizliklerin azaltılması gerektiğini; siyasal-toplumsal yapının etkilerinin ve sınırlı rasyonalitenin getirdiği bilgi paylaşım düzeyinin dikkate alınması gerektiğini, enformel kurallar ile ağ ilişkilerinin en aza indirgenerek olabildiğince öngörülebilir piyasa koşullarının yaratımasını savunur. Bunun ise ancak kurumların (oyuncu) ve oyunun kurallarının (enformelformel kurallar) ${ }^{16}$ iyi kurgulanması ile mümkün olacağını vurgular. ${ }^{17}$ Genel olarak YKi, kurumlar, organizasyonlar ve bunların etkileşimlerinin ekonomideki etkilerini inceler.

Daron Acemoğlu ve James A. Robinson “Ulusların Düşüşü" (2012) isimli kitaplarında ülkelerin coğrafyaları, verimli kaynakları, kültürleri benzer olsa da gelişmişlik düzeylerinin çok farklı olabileceğini vurgulamakta; gelişmişlik farklarının nedeninin ekonomik ve politik kurumların farklılığına dayandığını ifade etmektedirler. ${ }^{18}$ Dolayısıyla kurumsal

\footnotetext{
9 Erdoğan, 2016, s.34.

${ }^{10}$ Banarjee ve Ghatak'tan akt. Güler, 2012.

${ }^{11}$ Şenalp, 2007.

12 Joskow, 2004.

${ }^{13}$ Şenalp, 2007.
}

\footnotetext{
${ }^{14}$ Çetin, 2012

${ }^{15}$ Erdoğan, 2016.

16 North, 1991.

17 Şenalp, 2007; Çetin, 2012.

${ }^{18}$ Acemoğlu \& Robinson, 2012.
}

değişim süreci ve bütünleşme, gelişmişlik üstünde belirleyicidir. Destekler biçimde North $(1991)^{19}$ da piyasaların nasıl işlediğinden çok nasıl geliştiğini açıklayan neoklasik ekonomik teorinin ulusların gelişimini açıklamada yetersiz kaldığını belirtmektedir. Bu noktada kurumların ekonomilerde önemli bir olgu olduğunu dile getiren ilk isim ise Karl Polanyi olmuştur. Ayrıca Polanyi, karşılıklılık ilişkileri, piyasada siyasetin rolü gibi konulara da değinerek YKi ile ortaklaşmaktadır. ${ }^{20}$

YKI'ta önemli bir kavram olan kurum kavramı üç özellik üstünde temellenir: 1) kurumların oluşması ve varlıklarını sürdürmesi belirli kısıtlara ve kurallara bağlıdır 2) kurumlar öngörüye izin verir 3) kurumlar bireyler ve insan toplulukları arasındaki ilişkileri düzenler. Bu üç özellik bireylerin ve toplulukların ilişkilerini düzenlemelerinde belirsizliği azaltan rol üstlenir. ${ }^{21}$ Nitekim North’a (2002) göre de kurumlar, piyasa eylemlerinin ne şekilde sonuçlanabileceği konusunda belirlilik yaratarak piyasa aktörleri için güvenilir bir piyasa ortamı yaratırlar. North'a göre kurumlar ille de toplumsal açıdan etkin olsunlar diye kurulmazlar; kurumlar ya da formel kuralların varoluş nedeni, yeni kurallar düzenlemeye gücü yeten ve pazarlık gücü olanların çıkarlarına hizmet etmektir. ${ }^{22}$ Williamson (2000), kurumların hem oyunun kurallarını hem de oyuncuların sınırlarını belirlediğini vurgular. Her bir dönem değişen kuralların kuralsızlıktan farkı yoktur. ${ }^{23}$ Bu nedenle oyunun kuralları öncelikle anayasal düzende belirlenmelidir. Anayasal iktisat yaklaşımında devlet iyi bir toplum için gerekli olan mal ve hizmetleri üretmelidir. Ancak devlet bütün bu yetkilerini anayasal çerçevede kullanmalıdır. Yani devletin sınırsız yetkisi olmamalıdır. ${ }^{24}$ Kuralların önemi kadar kuralların belirlenme sürecinde tarafların pazarlık güçlerinin önemi de gözden kaçırılmamalıdır. Tarafların güçleri oyunun kurallarını zaman içinde değiştirebilir. ${ }^{25}$

Kurumlar, uzun yıllar boyunca bireyler arasında süregelen etkileşimin sonucunda ortaya çıkar ve evrilirler. Bir toplumda gelişen işbölümü ve uzmanlaşma, kurumsal evrilmenin temel kaynağıdır. ${ }^{26}$ Bireyler, kurumsal yapı içinde işbölümü ve uzmanlaşmanın sağladığı getiriden daha fazla pay almak için organizasyonları oluştururlar. Bireyler, değişimin niteliğini belirleyen sözleşmeleri iradi veya zorunlu olarak belirlerler. Bu sözleşmelerin bir araya gelmesiyle oluşan yapıyı organizasyon olarak tanımlayabiliriz. North'a (1991) göre tüm organizasyonlar (ticari birlikler, kooperatifler, ekonomik/politik organizasyonlar, siyasi partiler, yasama meclisleri, düzenleyici kurumlar, üniversiteler, okullar), bir sözleşme ilişkisinden başka anlam içermemektedir. ${ }^{27}$ Bireysel olarak sözleşmeler yoluyla piyasa ilişkilerini

\footnotetext{
${ }^{19}$ North, 1991.

${ }^{20}$ Polanyi, 1957.

21 Özveren, 2007.

22 North, 2002

${ }^{23}$ Williamson, 2000
}

\footnotetext{
${ }^{24}$ Aktan (2006)'dan akt. Doğan \& Kurt (2016).

${ }^{25}$ Kama, 2011, s. 199.

${ }^{26}$ Çetin, 2012, s. 51.

${ }^{27}$ North, 1991
} 
yürütmek yerine bir sözleşmeler bütünü olan organizasyon yoluyla ilgili faaliyeti yerine getirmek grup üyelerine daha fazla kazanç sağlayabilir. Organizasyonlar oyunculardır ama bireylerin kendileri değillerdir. Ortak bir amaç etrafinda toplanan bireylerin oluşturduğu gruplardan meydana gelirler. Organizasyonların öncelikli amacı (örneğin firma için) karı maksimize etmek ve (örneğin siyasi partiler için) tekrar seçilmek olabilir ama nihai amaç hayatta kalmaktır. Çünkü tüm organizasyonlar, kaynakların kıt ve bu nedenle rekabetin şiddetli olduğu bir dünyada yaşamaktadırlar. ${ }^{28}$

Hukukun çizdiği formel kurallar yanında özellikle gelişmekte olan ülkelerde yaygın görülen enformel kurallar da mevcuttur. ${ }^{29}$ Devletin ve formel kuralların etkin olmadığı durumlar enformel yapıların oluşumunu tetikler. ${ }^{30}$ Bir diğer durum da kuralların değiştirilmesidir. Kuralların değiştirilmesi formel kuralların yetersiz kaldığı durumlarda gündeme gelir. ${ }^{31}$ Sonuç olarak birbiriyle tutarlı olamadıkları için enformel kurallar ve formel kurallar arasında bir gerilim yaşanmaya başlar. Yaptırımın sıkı olmadığı durumlarda formel kuralların sıklıkla göz ardı edildiği görülür. Kurumsal yapılandırma ve formel kurallar siyaset kurumu tarafindan tanımlanır. Siyaset kurumunun üstünde, ekonomik kurum ve kuruluşların ve de sermaye piyasasındaki çıkar gruplarının etkisi ihmal edilemez. Dolayısıyla formel kurumsal çerçeve, yeterli pazarlık gücüne sahip olanların çıkarları doğrultusunda biçimlenecektir. ${ }^{32}$ Örneğin, kent rantının dağıtımında "patron-müşteri" ilişkilerinin kurulması ve sürdürülmesi, siyasetçilerin devletin kaynaklarını doğrudan dağıtmasına göre önemli üstünlüklere sahip olduğundan, karşılıklılık ilişkileri özellikle gelişmekte olan ülkelerde planlama disiplininde önemli bir iş yapma biçimi haline gelmiştir. ${ }^{33}$ Endonezya'da büyük konut şirketlerinin çoğunun politik elitler ile kurduğu ilişkiler buna örnek olarak verilebilir. ${ }^{34}$ Özetle, YKI'a göre enformel kurallar da formel kurallar kadar önem arz emektedir. Konut üretiminde kullanılacak arsa sunusunu yönlendirecek olan planlama ile karşılıklılık ilişkileri ve enformel kentsel gelişmeler arasında bir gerilim bulunmaktadır. Temel soru kurumsal ve yasal düzenlemelerin bu gerilimi azaltacak yönde olup olmadığıdır. Dolayısıyla devlet kanalıyla kurumsal arsa sunusunun aracı olan planlama, formel olana odaklanırken enformeli inmal etmemelidir. Bu durum plancıları geleneksel planlama yaklaşımlarından doğan sınırlııkları ve enformalitenin kurumsal içeriğini araştırmaya yöneltmektedir. Bu da görünmeyeni görünür yaparak daha geniş perspektiften bakmaya olanak sağlayacaktır.

Kaynakların kullanım ve dağıtımını yönlendiren planlama eylemi, mülk sahiplerinin bu kaynak kullanımından elde edecekleri faydanın düzeyini belirlediği için de

\footnotetext{
${ }^{28}$ North'dan akt. Çetin, 2012, s. 51.

${ }^{29}$ Panatiris, 2007.

30 North, 2002.

${ }^{31}$ Erder, 2015, s. 396
}



önem kazanmaktadır. ${ }^{35}$ Kentsel gelişmeye bağlı olarak oluşan kentsel arsa talebi, öncelikle kentin yakınında yer alan arazilerin imara dâhil edilmesine neden olur. Burada amaç plan kararlarıyla istenen sunuyu sağlamak ve yüksek toplumsal faydayı yaratmaktır. ${ }^{36}$ Alexander (1992), geleneksel olarak planlamanın kamunun müdahalesi olarak görüldüğünü ifade eder. Oysa planlama faaliyetleri sadece kamusal mülkiyetleri ya da kamusal yatırımları değil hatta daha geniş olarak özel sektör faaliyetlerini kapsar ve bu ikisi arasında bir köprü vazifesi görür. ${ }^{37}$ Rydin (2011), tüm grupları aynı anda tatmin etmenin mümkün olmadığından ve planlama eyleminin tüm tarafların beklentilerini karşılamasını beklemenin anlamlı olmayacağından, bazı grupların avantajı bazılarının ise dezavantajı konuma düşeceğinden bahseder. Buna rağmen, ekonomik aktörlerin gelecek zaman perspektifinde yatırım alanlarının koşullarını bilmesi ve yatırımlarını planlaması için planlar aracılığıyla yaratılan ve koşulları belirli bir piyasa ortamı gereklidir. ${ }^{38}$

Alexander (1992)'a göre kurumlar tarafindan yapılan planlar, hem ilgili yönetimin kendisine hem de yerel birimin sakinlerine, piyasa aktörlerine ve diğer ilgililere yer seçim ve yatırım kararlarının alınması ve bu kararların -piyasanın yapamayacağı bir yolla- koordinasyonunun sağlanmasında referans olabilecek bir çerçeve sunmaktadır. Arazi geliştirme yatırımları, yer seçim kararları ve diğer gelişmelerdeki belirsizlikler işlem maliyetlerini artıracak ve bu da formel olana koşut piyasa sistemi yaratılmasına neden olacaktı. ${ }^{39}$ Rydin (2011), işlem maliyetleri yüksek olduğunda konut inşaat sektörünün intiyaca değil talebe cevap verdiğini vurgulayarak, bunun ödeme gücü yüksek olan tüketicilere yönelik konut sunusuyla sonuçlandığını belirtir. ${ }^{40}$ Dolayısıyla, işlem maliyetleri yüksek olduğunda arsa sunusunun ihtiyaçtan ziyade talebe (ödeme gücü yüksek olan tüketicilere) yönelik olduğu bu nedenle kurumsal ve yasal düzenlemelerin bu eğilim dikkate alınarak yapılması gerektiği söylenebilir. Kurumlar ve oluşturdukları yasal düzenlemeler ile koşulları belli bir piyasa yaratılmaktadır. Bu piyasa koşullarında arazi geliştirme süreçleri işletilmektedir.

Buna göre Alexander (2001) arazi geliştirme sürecinin ilk evresini arazinin elde edilmesi olarak tanımlar. Bu evrede taraflar alıcl, satıcı, spekülatör, inşaatçı ya da herhangi bir birey, hane halkı ya da arsa almak isteyen kuruluşlar olabilir. İkinci evre finansmanın sağlanmasıdır. Finansman, finans kuruluşları, geliştiriciler, müteahhitler ya da hane halkı tarafindan sağlanabilir. Üçüncü evre arazinin hazırlanmasıdır. Bu süreçte profesyonel danışmanlar ve müteahhitler işlemi yapabileceği gibi inşaatçılar ya da hane halkı tarafindan da hizmet tedarik edilebilir. Hizmet temini piyasa koşulları altında ya da karşılıklılık ilişkileri temelinde sağ-

\footnotetext{
${ }^{35}$ Campbell\&Marshall, 2000, s. 297. $\quad{ }^{38}$ Rydin, 2011, s. 18

36 Özuğurlu, 2010, s. 378.

${ }^{37}$ Alexander, 1992, s. $190 . \quad{ }^{40}$ Rydin, 2011, s. 38.
} 
lanabilir. Dördüncü evre arazinin devridir. Hazırlanan arsa, geliştirici tarafindan müteahhit firmaya ya da hane halklarına satilır (ya da kiralanır). Bu aşamada spekülatörler de yer alabilir. ${ }^{41}$ Tüm bu süreçler ülkelerin planlama sistemine bağlı olarak değişebilmekte ancak genel olarak bu süreç tarifi ülkemizdeki arazi geliştirme süreçlerinin temel yapısını yansıtmaktadır.

Ülkemizde planlama sistemi, hiyerarşik, plan ve uygulama bütünlüğünü esas alan düzenleyici planlama sistemidir. ${ }^{42}$ Ancak plan uygulama süreçlerinde, kısa vadeli ve projeci planlama anlayışının benimsendiğ ${ }^{43}$ ve bunun mevcut planlama sistemi ile çeliştiği görülmektedir. Dolayısıyla imar planlarının konusu olan konut arsası sunusu, imar planları dışında müdahalelere konu olmaktadır. Örneğin arazi geliştirme sürecinde büyük ölçekli konut projeleri için kurallar ve uygulamalar arasında bazı farklılıklar bulunmakta ve bu durum süreçteki aktörler için önemli firsatlar sunmaktadır. ${ }^{44} 3194$ sayılı İmar Kanunu, 5393 sayılı Belediye Kanunu ve 5216 sayılı Büyükşehir Belediye Kanunu ile planlama yetkisinin yerel yönetimlere belirli ölçüde devredilmesi sağlanmıştır. 2003 sonrasında ${ }^{45}$ ise özel amaçlı planlar yapma yetkisiyle Toplu Konut İdaresi Başkanlığı'nın (TOKI) planlama sisteminden bağımsız olarak kendi planlarını yapmak ve onaylamak için yetkilendirildiği bilinmektedir. ${ }^{46}$ Ülkemizde müteahhitler ve GYO'ların (özel sektör) talebi ve yer yer baskısı ile özel araziler üzerine kamu tarafindan konut arsası sunusu geliştirilebilmektedir. Devletin konut piyasasındaki etkisi, yapacağı yasal düzenlemelerle piyasanın düzenlenmesi, yönlendirilmesi, teşviki yoluyla olabildiği gibi kamunun konut inşaatnna doğrudan girmesiyle de olabilmektedir. ${ }^{47}$

Genel olarak, büyükşehirlerde, devletin yürüttüğü konut arsası sunusu sürecine odaklanıldığında, çok büyük kamu arazisi stoğuna sahip olan TOKi'nin gelişme alanları üzerinde konut projeleri geliştirdiği, belediyeler ve Çevre ve Şehircilik Bakanlığı'nın (Ç̧̧B) ağırıkla kentsel dönüşüm projeleri gerçekleştirdiği gözlemlenmektedir. Öte yandan, büyükşehir belediyeleri kurdukları şirketler (İstanbul örneğinde Kiptaş) üzerinden ve belediyeler ya da TOKI ile anlaşarak ağılıklı olarak kamu arazilerinde inşa etmek üzere piyasaya konut üretmektedir. İlçe belediyeleri ise belediye mülkiyetindeki sınırlı alanlar üstünde imar planları yoluyla konut arsası sunusu yapmaktadırlar. Devletin merkez kurumlarının özellikle de büyük ölçekli konut projelerinde yer aldığı bilinmektedir. Bu durum, konut arsa sunusu ötesinde, çok güçlü bir aktör olarak devletin kendini piyasada ölçeklendirmesidir ki özel sektör açısından asimetrik bir piyasa yarattğı görüşüyle tartışımaktadır.

\footnotetext{
${ }^{41}$ Alexander, 2001, s. 58-62.

42 Özkan\&Türk, 2016.

${ }^{43}$ Brenner\&Theodore, 2005.

${ }^{44}$ Türk\& Korthals Altes, 2010.
}



${ }^{45}$ Oluğ, 2015.

${ }^{46}$ Özkan\&Türk, 2016.

47 Zariç, 2012, s. 7.

\section{Türkiye'de Konut Arsası Sunusu: 2000 Sonrası} Dönem

YKI bağlamında Türkiye'de konut arsası sunusu, arsa ve arazi düzenleme süreçlerine odaklanan ve ilk İmar Kanunu'nun çıktığı 1956 yılı ve sonrasındaki mevcut planlama kurumsal yapılandırması ve mevzuat düzenlemelerini dikkate alan kapsamlı bir doküman analizi yoluyla tartışmaya açılmıştır (bkz. Şekil 1). Patsy Healey'e (2011) göre, planlamanın yasal kurumsal araçlarının nasıl çalıştırıldığının ötesinde plancıların ilgilenmesi gereken konulardan biri de bunların ne amaçla geliştirildiğinin ve hangi değerleri oluşturduğunun analiz edilmesidir. ${ }^{48} \mathrm{Bu}$ bağlamda neoliberal ekonomi politikaları uzantısında konut arsası sunusunu yönlendiren yasalar ve yönetmelikler incelendiğinde ekonomik krizden çıkış ve tek parti iktidarına dayalı hükümet yönetimi ile birlikte şekillenen yasal değişiklikler bağlamında 2002 yılı kritik yıl olarak görülmektedir (bkz. Şekil 1).

Şekil 1'de görüleceği üzere büyük ölçekli toplu konut projelerine olanak tanıyan 2985 sayılı Toplu Konut Kanunu, şehrin gelişme alanlarında konut ihtiyacını karşılamaya yönelik konut alanlarının büyüklüğünü ve yerini belirten resmi plan belgelerinin süreçlerini tanımlayan 3194 sayılı İmar Kanunu, her yerleşmenin kendi dinamiklerine uygun konut arsası sunusu ile konut projeleri uygulamalarının çerçevesini çizen 5393 sayılı Belediye Kanunu, özelikle de meskun alanlardaki arsaların yeniden kentsel mekan üretiminde kullanılmalarını sağlayan 6306 sayılı Afet Riski Altındaki Alanların Dönüştürülmesi Hakkında Kanun gibi düzenlemeler, neoliberal ekonomi politikaları uzantısında, konut üretimini hızlandıracak yönde konut arsası sunusunu artormak hedefli, etkinliği yüksek yasal düzenlemelerdir. ${ }^{49}$ Bu yasalarla konut arsası sunusunda yetki sahibi kurumlar; ÇŞB, TOKi, Büyükşehir belediyeleri ve ilçe belediyeleri olarak tanımlanmaktadır.

Bu kurumlar içinde TOKi, piyasaya konut sunusunda temel aktörlerden biri haline gelmiştir. TOKi, sahip olduğu yetkilerle düzenleyici planlama sisteminin temel özelliklerinden biri olan hiyerarşik düzenin dışında kararlar alabilen; ${ }^{50}$ yapı denetim, bütçe vb. birçok denetimden muaf; ilaveten, gelir elde etme amacıyla özel şirketlerle ortaklık kurma yetkilerine sahip bir kuruluş olarak karşımıza çıkmaktadır. ${ }^{51}$ TOKi'nin konut projesi olarak belirlediği alanlara bakıldığında: imar planı içinde ya da dışında kaldıkları, meskun ya da gelişme bölgesinde olabildikleri, ilgili Belediye'nin olumsuz görüşü olsa da ÇŞB'nın onayıyla projelerin gerçekleştirebildiği, projelerin kendi mülkiyetindeki arsalar ya da satın alma ve kamulaştırma yoluyla elde edilen arsalar üzerinde

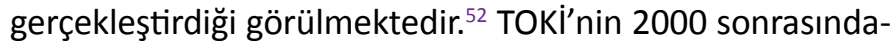

\footnotetext{
${ }^{48}$ Healey, $2011 . \quad \quad{ }^{51}$ Ruşen, 2013, s. 50.

${ }^{49}$ Çevikayak vd., 2013, s. $347 . \quad 52$ 17/3/1984 tarihli Resmi Gazete'de yayım-

${ }^{50}$ Özkan\&Türk, 2016.
} 
ki varlığını Oluğ (2015) şöyle nitelendirmektedir: “2000’ler sonrası neoliberal politikaların konut sektöründe ve kentte uygulanabilmesini sağlayacak güçlü bir devlet aygıttna ihtiyaç duyulmuştur. Bu devlet aygıtı da TOKi'dir. Bu doğrultuda 2003'ten itibaren gerçekleştirilen yasa değişiklikleriyle TOKi büyük bir güce ulaşmıştir". ${ }^{53}$

Konut arsası sunusunda önemli yetkilere sahip diğer bir devlet kuruluşu ise belediyelerdir. Belediyeler, imar planları aracılığıyla konut alanları büyüklüğünü nüfus projeksiyonları yoluyla belirlemektedir. Belirlenen konut alanları arsa düzenleme adımları çerçevesinde konut arsası haline getirilmekte ve konut inşaat için sunulmaktadır. 2005 yılında çıkan "Belediyelerin Arsa, Konut ve İşyeri Üretimi, Tahsisi, Kiralanması ve Satısına Dair Genel Yönetmelik" ile hem arsa ve arazi hem de konut üretimi konularında belediyelere geniş yetkiler verilmiştir. Yönetmelik hükümlerine göre belediyeler, düzenli kentleşmeyi sağlamak, beldenin konut, sanayi ve ticaret alanı ihtiyacını karşılamak amacıyla imarlı ve alt yapılı arsalar üretilebilir. Belediyeler, arsa temininde konut ve işyeri yapımında kredi kuruluşları, TOKi ve diğer ilgili kamu kurum ve kuruluşlarıyla ortak projeler yapabilir. ${ }^{54}$ Büyükşehir Belediyeleri aynı zamanda konut sunusu amacı ile şirket kurabilmektedir. Bunun ilk örneği İstanbul Büyükşehir Belediyesi'ne bağlı bir şirket olan KiPTAŞ'tır.

Mevzuatla gelen ve konut arsası sunusunu etkileyen düzenlemelerin kapsamı Şekil 1'den izlenebilmektedir. Kapsamlı bir doküman analizinin ürünü olan Şekil 1'deki kesik çizgili oklar, birbirinin devamı niteliğinde görülebilecek kurumlar ile bulguların hangi yasaya ve kuruma ait olduğunu göstermektedir. Şekil 1'de aynı renkler kurumların yetkilerini tanımlayan kanun ve yönetmelikler ile kurumun devamı niteliğindeki diğer kurumları ifade etmektedir. Şekil 1'den kurumların sürece hangi aşamada (planlama/ uygulama) dahil olduklarını da izlemek mümkündür. Şekil 1 yardımıyla, kurumların doğrudan arsa sunusu yapabilme yetkileri ve yetkileri ötesinde doğrudan arsa sunusu yapmalarına olanak sunacak durumlar irdelenmiştir. Şekil 1'den çıkarılan temel bulgular aşağıdaki gibi özetlenebilir:

- 3194 sayılı İmar Kanunu ve 6306 sayılı Afet Riski Altnndaki Alanların Dönüştürülmesi Hakkında Kanun'un konut arsası sunusu ve genel olarak kentsel yapılı çevre bağlamında en kapsamlı yasalar olduğu anlaşılmaktadır. Bu bağlamda etkili kurumlar ÇŞB, Büyükşehir Belediyeleri ve ilçe belediyeleridir. Buradaki önemli nokta 6306 sayılı yasada 3194 sayılı İmar Kanunu'nun yetkilerini kısıtlayıcı maddelerin bulunmasıdır.

- Kamulaştırma Kanunu ile mülkiyet hakkına hızla müdahale edilebildiği ve konut arsası sunum süreçlerinin hızlandırılabileceği anlaşılmaktadır. ÇŞB ile TOKi'nin, Bakanlar Kurulu'nca alınan kamu yararı gerekçeli ka- mulaştırma kararı doğrultusunda mülkiyete müdahale yetkisi bulunmaktadır.

- Yasalar doğrultusunda orman alanları, meralar, tarım alanları ve hazine arazilerinin konut arsası sunusuna konu olabileceği ortaya çıkmaktadır. Bu tür alanlardaki arsa sunusu genellikle Bakanlıklar ve TOKi gibi merkez kurumlar yoluyla gerçekleştirilmektedir.

- TOKi'nin Arsa Ofisi ve Emlak Konut ile birleşerek ve 09.07.2018 tarihli ve 703 sayılı KHK ile de ÇŞB'na bağlanarak $^{55}$ güçlü bir kurum haline geldiği söylenebilir. Geçirdiği yasal değişiklikler ile de fon verme işlevinden uzaklaşarak hüküm ve tasarrufunda bulunan hazine arazilerini konut projeleri için değerlendirebileceği anlaşılmaktadır.

- Çevre Düzeni Planı gibi üst ölçekli plan kararlarını veren ve büyük çaplı kentsel dönüşüm projelerini yürüten ÇŞB'nın arsa ve arazi düzenleme yetkisine de sahip olduğu ve yetkilerini bu doğrultuda kullanarak konut arsası sunusunda etkili bir aktör olabileceği görülmektedir.

- Son olarak, yerel yönetimlerin 1985'ten bu yana 3194 sayılı Kanun'dan gelen arsa sunusuna yönelik yetkilerinin (özellikle de Düzenleme Ortaklık Payı, Kamu Ortaklık Payı, ifraz, tevhid gibi arsa düzenleme işlemlerine yönelik) benzer şekilde (özellikle de 2002 sonrası) merkez kurumlara da verildiği görülmektedir. Ancak, tüm bu düzenlemeler ve yetki artırımına rağmen arsa düzenleme araçlarının 1995 yılından beri değişmediği tespit edilmiştir.

Şekil 1'de kurumsal ve yasal düzenlemelere geniş bir çerçeveden bakılmıştır. Konut arsası sunusu kapsamında, kurum ve aktörlerin konut arsası geliştirme süreçlerinde izlediği stratejiler, yürüttüğü işlemler ve kurumlar arası ilişkiler doğrultusunda detaylandırma ise Şekil 2'de özetlenmiştir. Şekil 1 gibi, Şekil 2 de kapsamlı bir doküman analizine dayanır. Şekil 2'den izlenebilen aktörler, aktörlerin konut arsası sunusuna yönelik izledikleri strateji, bu aktörlerin dayandığı temel kanun ve tüm bunların materyal karşılıkları yanı sıra kurumlar arası ilişkiler (yetki devri, arazi devri, protokol vb.) doküman analizinde yer almaktadır. Şekil 2 'den elde edilen bulgular ise aşağıdaki gibidir:

- Yetki genişliği bağlamında en dikkat çekici kurumlardan biri ÇŞB'dır. ÇDP hazırlamaktan, ifraz, tevhit işlemi yürütmek ve ruhsat vermeye kadar çeşitlenen yetkileriyle Bakanlık, resen işlemler yapabilmesi nedeniyle önemli bir kurumdur.

- Milli Emlak Genel Müdürlüğü genel olarak kamu arazilerinin yönetiminden sorumludur ve sahip olduğu arsalar üzerinde gelir getirici uygulamalar yapabilmek-

${ }^{53}$ Oluğ, 2015, s. $137 . \quad \quad \quad{ }^{54}$ Güven, 2007, s. 68. 


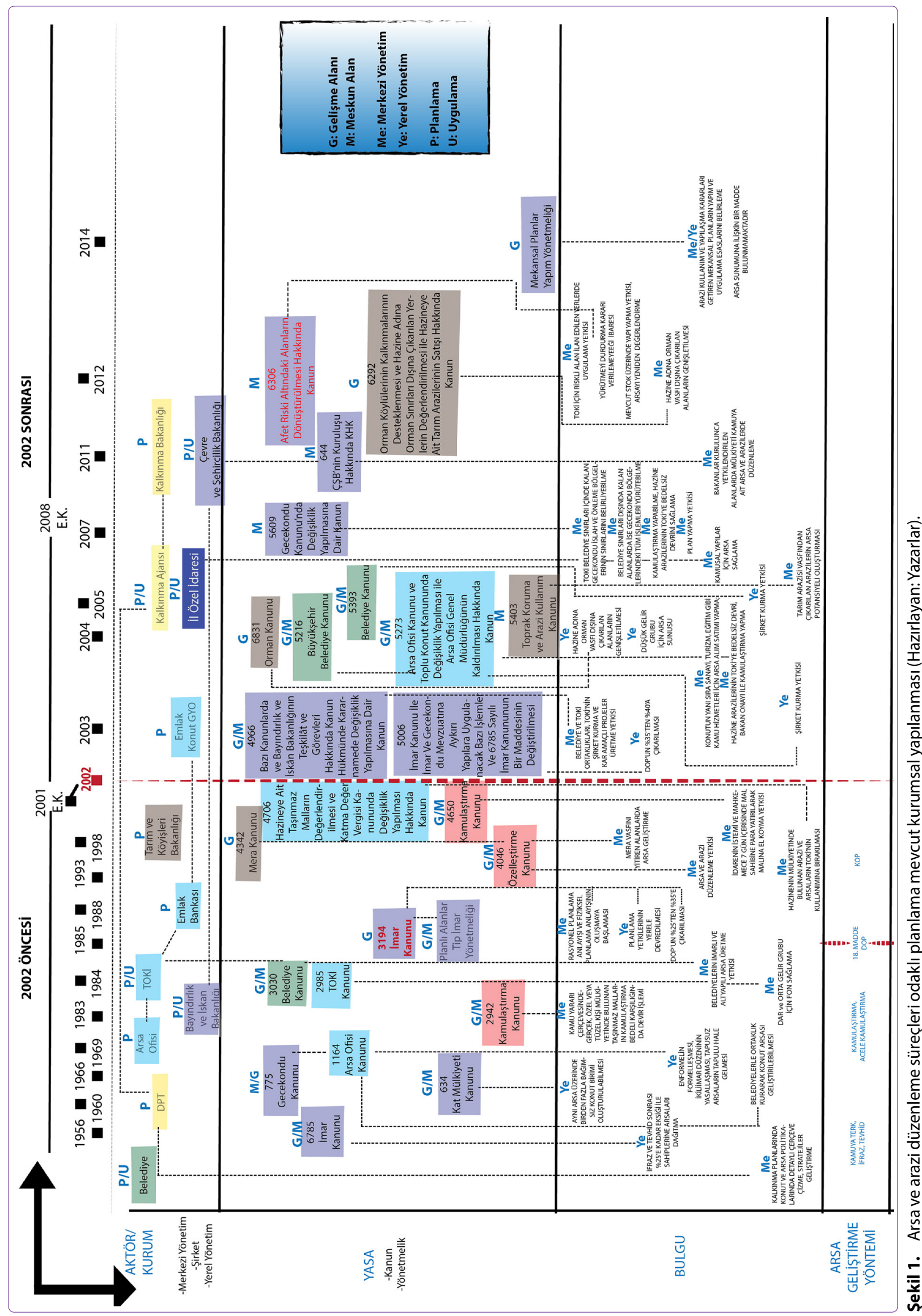




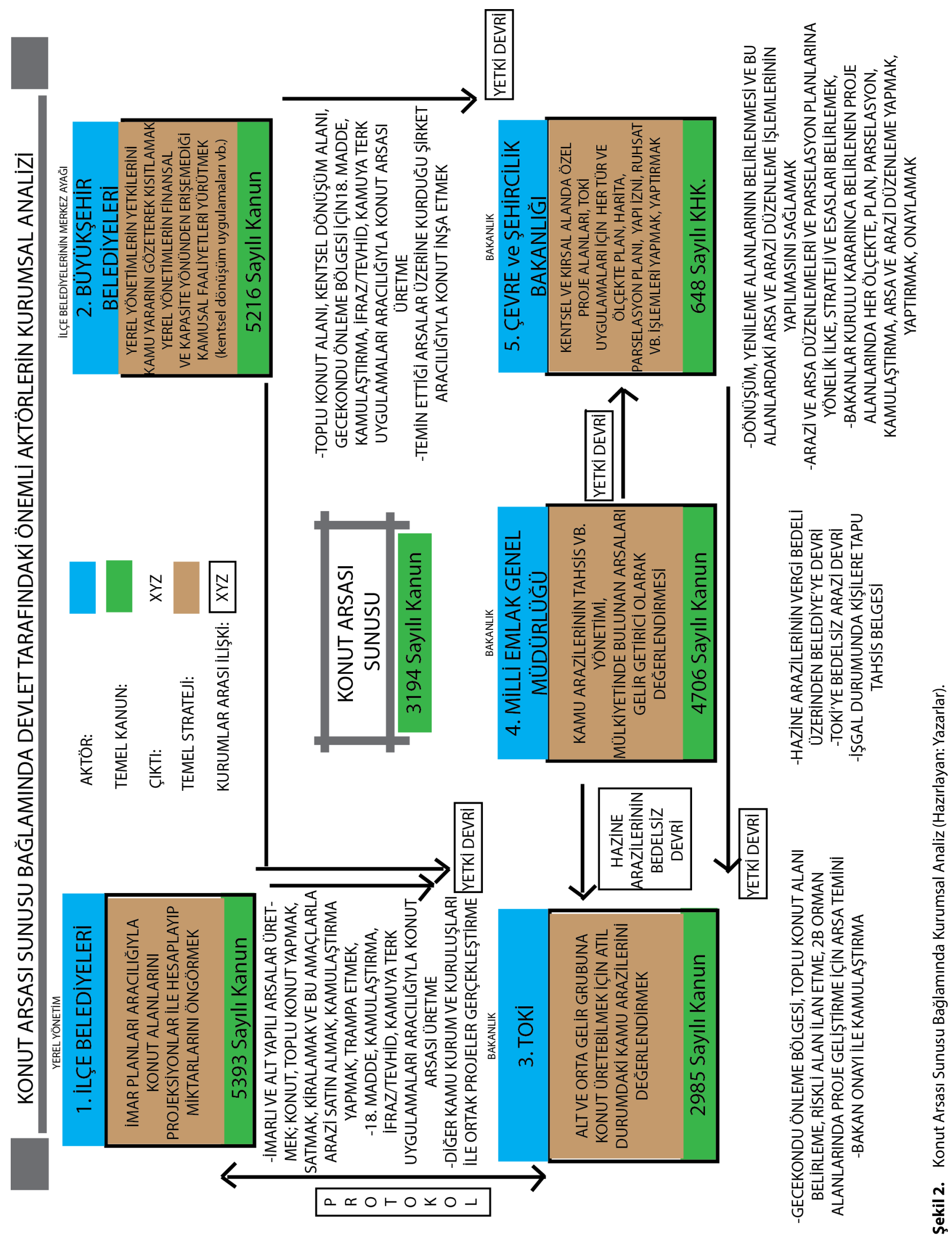


tedir. En fazla ilişkide olduğu kurumlar sosyal donat alanlarının ayrılması noktasında Bakanlıklar ve hazine arazilerinin bedelsiz devri noktasında ise TOKI'dir.

- Büyükşehir belediyelerinin ise şirket kurma yetkilerine dayanarak temin ettikleri arsalar üzerine konut inşa ederek konut sunusunda önemli bir aktör olabilecekleri anlaşılmaktadır.

- Genel olarak, kurumlar temel stratejileri ile uyumlu bir yol izlese de uygulamalarda bu stratejilere istisna oluşturacak şekilde eylemler gerçekleştirebilecekleri anlaşılmaktadır. (Örneğin, son yıllarda TOKi'nin alt gelir grubundan ziyade büyük kentlerde imara açılan büyük araziler üzerinde çeşitli tipte konutlardan oluşan ve üst gelir gruplarının satın alabileceği düzeyde lüks toplu konut yerleşmelerinin yapımını hızlandırması ve hazine arazilerinde hasılat paylaşımı modeliyle özel sektör ile işbirliği yapabilmesi ${ }^{56}$ )

- Toplamda 5 adet kurumun (TOKi, ilçe belediyeleri, Büyükşehir Belediyesi, ÇŞB, Milli Emlak Genel Müdürlüğü) 3194 sayılı yasa da dahil 6 temel yasa (3194, 5393, 5216, 2985, 4706 sayılı Kanunlar ve 648 sayılı KHK) ile konut arsa sunusunu şekillendirdiği anlaşımaktadır. Her ne kadar imar planları yerel yönetimlerin yetki ve sorumluluğunda olsa da merkezi yönetimin birden fazla kurumu ile bu yetkinin üstünde kararlar geliştirebileceğini göstermektedir.

- Yetki devirlerinin olduğu bölümler takip edildiğinde (Şekil 2) ise TOKi ve ÇŞB’nın en avantajlı kurumlar olduğu ortaya çıkmaktadır. Ayrıca TOKi'ye bedelsiz arazi devri ve ÇŞB'nın kamulaştırma yetkisi ile de bu kurumların mülkiyet hakları açısından kritik öneme sahip oldukları anlaşılmaktadır.

\section{Genel Değerlendirme}

Türkiye planlama pratiğinde ilçe belediyeleri aracılığıyla uygulama imar planları doğrultusunda yapılaşma koşulları ile konut alanları ve uygulaması belirlenmektedir. Ancak Şekil 2'den izlenebileceği gibi belediyeler dışında ve belediyelerden daha geniş yetkiler aracılığıyla, merkez kurumların yerel imar planları kararlarının ötesinde konut arsası sunma yetkilerinin olduğu görülmektedir. Bu durum hem planlamanın geniş anlamı ile çelişmekte hem kaynak kullanımında ekonomik verimlilik ve sürdürülebilirliği olumsuz etkileyebilmekte hem de kurumlar ve formel kurallar yoluyla yaratılması hedeflenen tam bilgilenmenin sağlandığı düzenli piyasa hedefiyle çelişmektedir. Dolayısıyla merkez kurumların konut arsası sunusu yerel planlara kayıtsız kalmakta ve bu planları dışsal almaktadır.

2012 yılında yürürlüğe giren 6306 sayılı Yasa ile meskun alandaki konut arsalarının yeniden piyasaya sunulmasına

\footnotetext{
${ }^{56}$ Taner, 2015, s. 9.
}

yönelik kapsamlı bir değişiklik gerçekleştirilmiştir. Devlet, bu kapsamlı yasa ile kurumlara ve özel sektöre yerleşik alanda yapılı arsaları yeniden sunuya katmayı olanaklı kılmıştr. Aynı yılda 6292 sayılı Yasa ile 2B olarak bilinen orman arazileri üzerindeki yapılar ve arsalar tapuya bağlanmıştr. Böylelikle piyasada alınır satllabilir durumda konut arsası miktarı artııımıştır. 5273 sayılı Yasa ile hazine arazilerinin TOKi'ye bedelsiz devri sağlanmıştır. 5216 sayılı Yasa ile mücavir alanlar kaldırılarak imar planı uygulanabilecek sınırlar genişletilmiştir. Tüm bunlarla konut arsası sunusu sağlayabilecek alanlar ve araçlar artmıştr. 644 sayılı KHK ile ÇŞB kurulmuştur. Böylelikle bakanlar kurulu yetkisi ile arsa ve arazi düzenleme yetkisi belediyeler dışında merkezi bir kuruma daha verilmiştir.

Yapılan kurumsal ve yasal düzenlemeler YKi'ın temel söylem ve kavramları bağlamında tartş̧ılacak olursa; a) YKi teorisinin, kurumsal ve yasal düzenlemelerin iyi kurgulanmadığı durumda enformalite, karşılıklıık ilişkileri ve belirsizliklerin artacağı söylemiyle ülkemizdeki konut arsası sunum süreçleri örtüşmektedir. Nitekim kurumsal düzen çerçevesinde yaratılan piyasa ortamının, oluşan ekonomik değerin kamuya geri döndürülmesine yönelik politikalardan ziyade birey faydasını öne çıkarabilecek ve bunun yaratılması için de karşılıklılık ilişkilerinin ve politik gücün etkin olarak kullanılmasına zemin hazırlayacak biçimde oluşturulduğu anlaşılmaktadır. Birden fazla kurumun, aynı alanda, farklı yetki ve sorumluluklar doğrultusunda konut arsası sunusu yapabilir olması da belirsizliği artıran bir faktör olarak görülmektedir. Nitekim kurumsal ve yasal düzenlemeler incelendiğinde dar gelir gruplarının barınma intiyaçlarını önceleyecek politikaların uygulatılmasına yönelik sorumlulukları ve yaptrımları net tarifleyen bir süreç şemasının çıkmadığı görülmektedir.

b) YKi teorisi bireylerin sınırlı rasyonaliteye sahip olduğunu ve tam bilgilenme sağlayamayacaklarını öne sürmektedir. Bu bağlamda, oyunun kurallarını belirleyen devlet kurumları avantajı konumda olmaktadır. Hazine arazilerinin aktarımı yoluyla çok büyük bir arsa stoğuna sahip olan, TOKi'nin konut arsası sunusunda en avantajlı devlet kurumu olduğu anlaşılmaktadır. TOKi'nin bir diğer avantajı da işlem maliyetleri noktasında devreye girmektedir. Konut sunusunda en önemli maliyet kalemi olan arsa için bedel ödememesi TOKi'yi diğer sunu aktörlerinden farklılaştırmakta ve işlem maliyetlerini önemli oranda düşürmektedir.

TOKi'nin 2000 sonrası geçirdiği yasal değişiklikler, Williamson'ın (2000) her bir dönem değişen kuralların kuralsızıktan farkı olmadığı ifadesine bir örnek teşkil etmektedir. ${ }^{57}$ TOKi, 1984 yılında çıkan 2985 sayılı Kanun'dan itibaren madde iptali, madde ekleme, KHK düzenlemesi dahil 27 adet değişiklik geçirmiştir. Şirket kurmak, riskli

\footnotetext{
${ }^{57}$ Williamson, 2000.
} 
alan ilanı, 2B orman alanlarında proje geliştirme, gecekondu önleme bölgesi ilan etme, 3194 sayılı kanundaki imar yetkilerine belediyeler yerine sahip olabilme, avan proje üzerinden ruhsat verme TOKi'nin yetki genişliğine örnek olarak verilebilecekler arasındadır. ${ }^{58}$ Yetki genişliği ve farklı mekanlarda farklı ölçeklerde konut arsası sunusu yapabilme, pazarlık gücü olanların çıkarlarına yönelik hamlelere zemin hazırlamaktadır.

Sonuç olarak devlet konut arsası sunusunda kurumsal ve yasal düzenlemeyi yönlendirmiş ve bu düzenlemelerin çerçevesini çizmiş olsa da sunu büyüklüğü ölçülebilir/ kontrol edilebilir değildir; tam bilgilenmenin sağlandığı, koşulları belirli bir konut sunusu piyasasının yaratılamamış olduğu anlaşılmaktadır. Konut arsa sunusunun planların öngörüsü dışında ve hatta ötesinde gerçekleştiği söylenebilir ve bunun sebepleri şöyle sıralanabilir: a) TOKi'nin konut piyasasına kendi arsaları ve belirlediği konut miktarı oranında dahil olabilmesi, b) belediyelerin sahip olduğu ve geliştirmek üzere sunduğu arsalara yönelik karşılıklı ağ ilişkileri aracılığıyla baskı kurmaya açık oluşu, c) özel sektörün kamunun sahip olduğu yasal ve kurumsal gücün gölgesinde kendine alan yaratmak üzere kamunun sahip olduğu bilgiye erişmesi

Son olarak, Temmuz 2018 itibariyle 703 sayılı KHK ile "Mahalli idareleri ve bunların merkez idare ile olan alaka ve münasebetlerini düzenlemek" ifadesi eklenip Yerel Yönetimler Müdürlüğü kurularak yerel yönetimlerin yönetiminin ve Milli Emlak Genel Müdürlüğü'nün ÇŞB'na bağlanması $^{59}$ konut arsası sunusunda devletin etkinliğini artırmak ve dolayısıyla merkeziyetçi yapıyı kuvvetlendirmekteki stratejisini sürdüreceğine yönelik önemli bir ipucu olarak görülmektedir.

\section{Kaynaklar}

Acemoğlu D. \& Robinson J. A., (2012) Ulusların Düşüşü: Güç, Refah ve Yoksulluğun Kökenleri, İstanbul, Doğan Kitap.

Alchian, A. A., \& Demsetz, H. (1973) The Property Rights Paradigm. The Journal of Economic History, 33(1), s. 16-27.

Aktan, C. C. (2006) "Kurumsal iktisat, Kurallar, Kurumlar ve Ekonomik Gelişme". Sermaye Piyasası Kurulu Yayınları, No:194, Ankara.

Alexander, E.R. (1992) "A Transaction Cost Theory of Planning". Journal of the American Planning Association, 58(2), pp. 190-200.

Alexander, E. R. (2011) "A Transaction Cost Theory of Land Use Planning and Development Control". The Town Planning Review, 71(1), pp. 45-75.

Altınok, E. (2012) “Kentsel Mekânın Yeniden Organizasyonunun Ekonomi Politiği ve Mülkiyete Müdahale 2000 Sonrası Dönemde İstanbul TOKi Örneği", Basılmamış Doktora Tezi, Yıldız Teknik Üniversitesi, Şehir ve Bölge Planlama.

${ }^{58}$ Resmi Gazete'de yayımlanan TOKi yasa değişikliklerinin derlemesinden oluşturulmuştur.

${ }^{59}$ 22/06/2018 tarihli Resmi Gazete yayımlanan Bakanlar Kurulu Kararı.
Brenner, N. \& Theodore, N. (2005) "Neoliberalism and the Urban Condition", City, 9(1), pp. 101-107.

Campbell, H. \& Marshall, R. (2000) “Moral Obligations, Planning and the Public Interest: A Commentary on Current British Practice", Environment and Planning B: Planning and Design, Volume:27, pp. 297-312.

Coase R. (1937) "The Nature of The Firm". Economica, New Series, Vol. 4, No. 16.

Çetin, T. (2012) "Yeni Kurumsal Iktisat", Sosyoloji Konferansları, No:45 (2012-1), s. 43-73.

Çevikayak G., İşven, M.C. \&Yüksel, N. (2013) “Planlamada Kamu Yararı Bağlamında İzmir'de Neoliberal Kentleşme Uygulamaları", TMMOB 2. İzmir Kent Sempozyumu, s. 345-360.

Doğan Z. \& Kurt Ü. (2016) "Yeni Kurumsal İktisadın Dalları", Journal of Life Economics Dergisi, s. (115-130).

Erder, S. (2015) İstanbul Bir Kervansaray (mı)?, İstanbul, İstanbul Bilgi Üniversitesi Yayınları.

Erdoğan S., (2016) “Kurumsal Yapı ve Ekonomik Büyüme İlişkisi: Gelişmiş ve Gelişmekte Olan Ülkeler İçin Karşılaştırmalı Bir Analiz", Basılmamış Yüksek Lisans Tezi, Mustafa Kemal Üniversitesi, iktisat Fakültesi.

Friedmann, J. (2005) "Globalization and the Emerging Culture of Planning". Progress in Planning, 64(3), pp. 183-234.

Güler, E. (2012) "Geçiş Ekonomileri ve Yeni Kurumsal iktisat'ın Yeniden Yükselişi”, Doğuş Üniversitesi Dergisi, 13(1), s. 52-68.

Güven Ö. (2007) "Büyük Konut Projeleri İçin Arazi ve Arsa Edinim Metodları: İstanbul Örneği”, Basılmamış Yüksek Lisans Tezi, İstanbul Teknik Üniversitesi, Gayrimenkul Geliştirme Bölümü.

Healey, P. (2011) "Civic Capacity, Progressive Localism and the Role of Planning", RTPI Nathaniel Lichfield Memorial Lecture.

Joskow P.L. (2004) "New Institutional Economıcs: A Report Card", International Society of New Institutional Economics, Budapest, Hungary.

Kama, Ö. (2011) "Yeni Kurumsal İktisat Okulunun Temelleri". Gazi Üniversitesi İktisadi ve İdari Bilimler Fakültesi Dergisi 13/2, 183-204.

North, D. (1991) "Institutions", Journal of Economic Perspectives, c.5, pp. 97-112.

North, D. (2002) Kurumlar, Kurumsal Değişim ve Ekonomik Performans, Çev. G. Ç. Güven, İstanbul, Sabancı Üniversitesi Yayınları.

Oluğ, Serdar. (2015) "Bir Kamu Politikası Aktörü Olarak Toplu Konut İdaresi Başkanlığı'nın (TOKi) Değerlendirilmesi”, Basılmamış Yüksek Lisans Tezi, Dokuz Eylül Üniversitesi, Kamu Yönetimi.

Özkan A., Türk Ş.Ş. (2016) "Emergence, Formation And Outcomes of Flexibility in Turkish Planning Practice", IDPR, 38 (1).

Özuğurlu, S.B. (2010) Toprak Mülkiyeti, Sempozyum Bildirileri, Ankara, Memleket Yayınları.

Özveren, E. (2007) Kurumsal İktisat, Ankara, İmge Kitabevi Yayınları.

Panatiris, E. (2007) Prosperity Unbound: Building Property Markets With Trust, Palgrave, Macmillan.

Polanyi, K. (1957) The Great Transformation: The Political and Economic Origins of Our Time. Beacon Press, Boston.

Ruşen Z. (2013) "Konut Üretiminde Bir Yönetişim Modeli Olarak TOKi”, Basılmamış Yüksek Lisans Tezi, Beykent Üniversitesi, Mimarlık Anabilim Dalı.

Rydin, Y. (2011) The Purpose of Planning, Policy Press, U.K. 
Şenalp, Mehmet Gürsan (2007) Dünden Bugüne Kurumsal İktisat. (Der: Eyüp Özveren). Kurumsal İktisat içinde s.15-43, Ankara, İmge Kitabevi.

Taner i. (2015) "Toplu Konut İdaresinin Konut Politikasının Değişimi: 1984-1989 Arası Konut Üretimine Kaynak (Kredi) Ayrılarak Desteklenmesi ve 2002 Sonrası Doğrudan Konut Üretimi”. (www.hkmo.org.tr) [Erişim Tarihi:29.10.2016).

Tekeli İ. (2009) Kentsel Arsa Altyapı ve Kentsel Hizmetler, İstanbul, Tarih Vakfi Yurt Yayınları.

Türk, Ş.Ş. \& Korthals Altes, W.K. (2010) "Institutional Capacities in the Land Development for Housing on Greenfield Sites in
Istanbul", Habitat International, 34, pp. 183-195.

Williamson, O. E. (1975) Markets and Hierarchies: Analysis and Antitrust Implications, Free Press, New York.

Williamson, O. E. (2000) "The New Institutional Economics: Taking Stock, Looking Ahead", Journal of Economic Literature. V.38, pp. 595-613.

Winarso \& Firman, (2002) Dieleman, (2011). “Claiming Spaces and Rights in the City", Routledge Research on Urban Asia.

Zariç, S. (2012) "Türkiye'de Kentsel Planlama ve TOKİnin Planlama Yetkilerindeki Genişlemenin Boyutları", Akademik Bakış Dergisi, Sayı: 28. 